\title{
RISIKO PERKAWNAN USIA MUDA PADA MASYARAKAT DESA SRIAMUR TAMBUN UTARA BEKASI
}

\author{
Nur Fajniah ${ }^{1, a)}$, Sitti Nursetiawati ${ }^{1, b)}$, Cholilawati ${ }^{1, c)}$ \\ a)nurfajriah77.nf@gmail.com \\ 1Program Studi Pendidikan Kesejahteraan Keluarga \\ 2P rogram Studi Pendidikan Tata Rias \\ 3 P rogram Studi Pendidikan Tata Busana \\ F akultas Teknik, Universitas Negeri J akarta \\ J In. Rawamangun Muka, J akarta Timur.13220
}

\begin{abstract}
Abstrak
Dalam perkawinan terdapat ketentuan usia yang dianjurkan saat akan melangsungkan perkawinan dimana usia memiliki peran dalam menentukan kesiapan dalam memasuki mahligai rumah tangga. Namun berdasarkan data yang dihimpun Kantor Urusan Agama (KUA) Tambun Utara, pada Desa Sriamur terdapat 93 laki-laki dengan rentang usia 19-25 tahun dan 49 perempuan dengan rentang usia 16-20 tahun yang melangsungkan perkawinan usia muda. Tujuan penelitian ini adalah untuk mengetahui risiko melakukan perkawinan usia muda. Penelitian ini dilakukan di Desa Sriamur Tambun Utara Bekasi. Metode Penelitian ini menggunakan metode penelitian kualitatif deskriptif dengan teknik sampling snowball sampling dan purposive sampling. Populasi pada penelitian ini adalah perempuan yang melakukan perkawinan usia muda pada usia 15-19 tahun. Hasil penelitian ini menyatakan bahwa risiko yang paling banyak diterima adalah segi pendidikan dimana seluruh responden memiliki tingkat pendidikan yang rendah dan tidak memungkinkan untuk melanjutkannya kembali. Kemudian pada segi kesehatan terdapat dua responden yang mengalami gangguan pada kesehatan reproduksi yaitu mengalami keguguran dan bayi lahir prematur. Pada segi fisik terdapat tujuh responden yang tidak dapat mengembangkan keterampilannya dan sembilan responden yang tidak bekerja setelah menikah. Pada segi mental terdapat tiga responden yang merasa stres dan kaget pada kondisi mental dan tujuh responden merasa terganggu kebutuhan pribadinya setelah menikah. Pada segi kependudukan terdapat enam responden yang memiliki anak lebih dari dua orang dan lima responden yang memiliki anak lebih dari dua orang namun juga ikut serta program keluarga berencana. Selanjutnya pada segi kelangsungan rumah tangga terdapat satu responden yang mengalami konflik rumah tangga dan menyelesaikan konflik rumah tangga tersebut dengan bercerai.
\end{abstract}

Kata Kunci: perkawinan usia muda, risiko, masyarakat desa.

\section{Risk of Early Marriage at Sriamur Village in North Tambun Bekasi}

\begin{abstract}
In marriage there are provisions recommended age to enter into marriage where age has a role in determining the readiness to enter hous ehold mahligai. However, based on data compiled by the Office of Religious Affairs (KUA) Tambun Utara, in the Sriamur village there are 49 women with an age range 16-20 years into marriage a young age. The purpose of this study was to know the risk of doing early marriage. This research method using descriptive qualitative research method with a snowball and purposive technique sampling. The results of this study showed that the risk of the most widely accepted is the terms of education in which all respondents had a low level of education and did not allow to continue. Then in terms of health, there are two respondents with problems of the reproductive health had a miscarriage and premature birth. In physical terms, there are seven respondents were not able to develop their own skills and nine respondents who do not work after marriage. In mental terms, there are
\end{abstract}


three respondents who felt her mental condition are stressed and shocked and seven respondents felt her personal needs was disturbed after marriage. In terms of population there are six respondents who had children more than two people and five respondents who had children more than two people but also to join the Keluarga Berencana program. Furthermore, in terms of the survival of the household, there is one respondent who had household conflict and resolved household conflict with divorce.

Keyword : early marriage, risk, villagers

\section{PENDAHULUAN}

Naluri makhluk masing-masing memiliki pasangan dan berupaya untuk bertemu dan mencari pasangannya. Saat telah menemukan pasangan yang tepat maka pasangan tersebut akan menentukan untuk membentuk suatu ikatan dibawah ikatan perkawinan. Menurut Undang-Undang Nomor 1 Tahun 1974 perkawinan ialah ikatan lahir bathin antara seorang pria dengan seorang wanita sebagai suami isteri dengan tujuan membentuk keluarga (rumah tangga) yang bahagia dan kekal berdasarkan Ketuhanan Yang Maha esa. Namun tidak semua perkawinan dilaksanakan sesuai sebagaimana anjuran khususnya pada segi usia pasangan yang akan melangsungkan perkawinan. Fenomena perkawinan usia muda sudah menjadi hal biasa yang terjadi pada masyarakat Indonesia.

Perkawinan usia muda adalah suatu perkawinan seorang pria dengan seorang wanita yang mana salah satunya atau keduanya relatif berusia muda. Perkawinan merupakan hal yang harus dipersiapkan dengan matang tidak hanya finansial saja, namun banyak segi kehidupan yang harus dipersiapkan agar pasangan siap saat memasuki babak baru dalam hidupnya. Berdasarkan data yang dihimpun Kantor Urusan Agama (KUA) Tambun Utara Bekasi, 8 Desa yang ada di wilayah Tambun Utara tercatat seluruhnya memiliki masyarakat yang melangsungkan perkawinan usia muda baik laki-laki maupun perempuan. Desa tertinggi yang tercatat dengan angka perkawinan usia muda tertinggi yaitu Desa Sriamur sebanyak 93 laki- laki dengan rentang usia 19-25 tahun dan 49 perempuan dengan rentang usia 16-20 tahun saat melangsungkan perkawinan. Ini menjadi fenomena yang sudah dianggap biasa terjadi pada lingkungan masyarakat di desa tersebut karena mayoritas masyarakatnya serta pengalaman orang tua yang juga melangsungkan perkawinan di usia muda sehingga paham tersebut menjadi turun temurun hingga hari ini.

Perkawinan usia muda ini jelas dapat memberikan risiko pada masyarakat yang melakukannya. Dilihat dari usia mempelai laki-laki dan perempuan masih dalam tahap remaja tengah 15-18 dan remaja akhir 18-21. Dimana remaja pada fase ini masih dalam pencarian identitas diri sehingga akan ada fase yang terpotong karena sudah harus siap menghadapi hidup berumah tangga dan siap menjadi orang tua. Segi mental ini akan berkaitan pada segi kelangsungan rumah tangga dimana didalamnya akan terjadi konflik dalam rumah tangga. Jika konflik rumah tangga selalu diselesaikan dengan ego masing-masing pasangan yang masih remaja dan masih labil maka memungkinkan konflik rumah tangga tersebut tidak terselesaikan dengan baik dan berujung pada perceraian. Pada usia ini remaja seharusnya masih mengenyam pendidikan, sehingga jika remaja sudah melangsungkan perkawinan maka dipastikan masyarakat yang melangsungkan perkawinan usia muda memiliki pendidikan yang rendah.

Pada perempuan, usia ini belum dianggap tepat untuk melangsungkan perkawinan mengingat sistem reproduksi yang belum siap untuk dibuahi sehingga memungkinkan berisiko pada segi kesehatan reproduksi. Usia ini dianggap usia yang produktif untuk bekerja, namun jika sudah melangsungkan perkawinan memungkinkan usia produktif ini tidak dimanfaatkan dengan baik. Jika sudah memiliki anak dan kewajiban dalam rumah tangga maka hal tersebut akan menjadi alasan perempuan untuk tidak bekerja setelah melangsungkan perkawinan. Perkawinan usia muda juga menyumbangkan angka kelahiran yang besar terutama di desa. Puncak umur melahirkan wanita di daerah perkotaan adalah 25-29 tahun (145 anak per 100 wanita) sedangkan di daerah perdesaan 
adalah 20-24 tahun (156 anak per 100 wanita). Ini menunjukan bahwa perkawinan usia muda menyumbangkan angka yang cukup besar dalam pertumbuhan penduduk (SDKI 2012).

Berdasarkan pembahasan di atas, maka dapat diketahui bahwa perkawinan usia muda menjadi fenomena yang terjadi secara turun menurun. Pentingnya penelitian dan risiko yang ditimbulkan jika penelitian ini tidak dilakukan, maka peneliti tertarik untuk meneliti fenomena perkawinan usia muda yang ada di Desa Sriamur denga judul "Risiko Perkawinan Usia Muda Pada Masyarakat Desa Sriamur Tambun Utara Bekasi".

\section{METODOLOGI PENELITIAN}

Tempat penelitian yang dipilih peneliti adalah Desa Sriamur Tambun Utara Bekasi. Peneliti memilih lokasi tersebut karena Desa Sriamur merupakan desa dengan angka tertinggi dimana masyarakatnya melangsungkan perkawinan usia muda. Waktu penelitian dimulai sejak bulan April 2016 sampai bulan Juni 2016. Subjek penelitian merupakan orang yang akan diteliti dalam berjalannya sebuah penelitian. Subjek penelitian ini adalah perempuan berusia 15-19 tahun pada saat melangsungkan perkawinan.

Pada penelitian ini menggunakan penelitian kualitatif yang bersifat deskriptif. Menurut Moleong (2010:6) penelitian kualitatif adalah penelitian yang bermaksud untuk memahami fenomena tentang apa yang dialami oleh subjek penelitian misalnya perilaku, motivasi, tindakan dan lain-lain. Pada penelitian ini, teknik sampling yang digunakan adalah purposive sampling dan snowball sampling.

Pada penelitian ini teknik dan prosedur pengumpulan data yang digunakan yaitu:

1. Observasi

Dalam penelitian ini akan dilakukan observasi terbatas yaitu observasi yang hanya dilakukan pada saat-saat tertentu saja. Observasi dilakukan untuk mengumpulkan data sesuai dengan sifat penelitian karena mengadakan pengamatan secara langsung dimana peneliti juga menjadi instrumen atau alat dalam penelitian. Pada saat observasi, peneliti memperhatikan tempat tinggal, lingkungan rumah, tetangga serta kegiatan yang biasa dilakukan oleh anggota keluarga.

2. Wawancara

Wawancara kualitatif dilakukan untuk memperoleh pengetahuan yang lebih subyektif yang dipahami individu berkenaan dengan topik dan masalah yang sedang diteliti dan bermaksud melakukan eksplorasi terhadap fenomena tersebut.

3. Observasi

Teknik dan prosedur berupa observasi adalah suatu usaha untuk mendapatkan gambaran mengenai suatu peristiwa secara kasar. Observasi dilakukan untuk mengumpulkan data sesuai dengan sifat penelitian karena mengadakan pengamatan secara langsung dimana peneliti juga menjadi instrumen atau alat dalam penelitian.

4. Dokumentasi

Dokumentasi merupakan catatan peristiwa yang sudah berlalu. Dokumentasi bisa berupa tulisan, gambar, atau karya-karya menumental dari seseorang. Dokumentasi yang termasuk dalam tulisan misalnya catatan harian, sejarah kehidupan (life histories), cerita, biografi peraturan, dan kebijakan. Dokumentasi yang berupa gambar misalnya, foto, gambar hidup, sketsa dan lain-lain (Sugiyono, 2012: 326). Studi dokumentasi merupakan pelengkap dari penggunaan observasi dan wawancara dalam penelitian kualitatif. Hasil penelitian dari observasi akan lebih kredibel/dapat dipercaya jika didukung dengan sejarah pribadi, masyarakat ataupun aoutobiografi.

Analisis data kualitatif merupakan upaya yang dilakukan dengan jalan bekerja dengan data, mengorganisasikan data, memilah-milahnya menjadi satuan yang dapat dikelola, mencari dan menemukan pola penting yang akan dipelajari dan memutuskan apa yang dapat diceritakan kepada orang lain. Analisis data kualitatif terdiri dari tiga alur kegiatan yang terjadi secara bersamaan yaitu: reduksi data, penyajian data, penarikan kesimpulan/verifikasi dijelaskan sebagai berikut: 
1. Reduksi data

Reduksi data merupakan bentuk analisis yang menajamkan, menggolongkan, mengarahkan, dan mengorganisasi data sehingga kesimpulan akhir dapat diambil. Merupakan kegiatan merangkum, memilih hal-hal yang pokok, memfokuskan pada hal-hal yang penting, mencari tema dan polanya.

2. Penyajian data

Penyajian data merupakan salah satu dari teknik analisis data kualitatif. Penyajian data merupakan kegiatan ketika sekumpulan informasi disusun, sehingga memberi kemungkinan akan adanya penarikan kesimpulan. Bentuk penyajian data kualitatif dapat berupa teks naratif (berbentuk catatan lapangan), matriks, grafik, jaringan dan bagan.

3. Kesimpulan/verifikasi

Kesimpulan awal yang dikemukakan masih bersifat sementara dan akan berubah bila tidak ditemukan bukti-bukti yang kuat yang mendukung pada tahap pengumpulan data berikutnya. Tetapi apabila kesimpulan yang dikemukakan pada tahap awal, didukung oleh bukti-bukti yang valid dan konsisten saat peneliti kembali ke lapangan mengumpulkan data, maka kesimpulan yang dikemukakan merupakan kesimpulan yang kredibel.

Uji keabsahan data pada penelitian kualitatif terdiri dari beberapa kriteria. Dalam penelitian kredibilitas terdapat teknik triangulasi dalam proses pengujian, ini diartikan sebagai pengecekan data dari berbagai sumber dengan berbagai car dan berbagai waktu. Terdapat triangulasi sumber, triangulasi metode atau teknik yang dijelaskan sebagai berikut:

1. Triangulasi sumber

Triangulasi sumber untuk mengkaji kredibilitas data dilakukan dengan cara mengecek data yang telah diperoleh melalui beberapa sumber.

2. Triangulasi teknik

Triangulasi teknik untuk menguji kredibilitas data dilakukan dengan cara mengecek data sumber yang sama dengan teknik yang berbeda. Misal data diperoleh dengan wawancara, lalu dicek dengan observasi dan dokumentasi.

3. Triangulasi waktu

Waktu juga mempengaruhi kredibilitas data. Data yang dikumpulkan dengan teknik wawancara di pagi hari pada saat narasumber masih segar, belum banyak masalah akan memberikan data yang lebih valid sehingga lebih kredibel.

\section{HASIL DAN PEMBAHASAN}

Berdasarkan hasil wawancara pada penelitian ini, seluruh responden memiliki risiko yang berbeda-beda. Pada segi kesehatan reproduksi, terdapat dua responden dari lima belas responden yang berisiko keguguran dan bayi lahir premature. Perkawinan usia muda memiliki risiko pada segi kesehatan reproduksi karena dinding rahim belum terlalu kuat untuk menopang embrio. Selain itu rahim belum siap untuk menerima kehamilan sehingga menyebabkan keguguran dan kelahiran premature tersebut. (Majalah Hamil Online, 2014). Ditinjau dari segi kesehatan, perkawinan usia muda meningkatkan angka kematian bayi dan ibu, risiko komplikasi kehamilan, persalinan dan nifas (Widyastuti, 2011:108)

Berdasarkan hasil penelitian, segi fisik merupakan risiko tertinggi kedua yang diterima seluruh responden. Responden yang melakukan perkawinan usia muda tidak mampu mengembangkan kembali keterampila fisiknya. Sedangkan responden tersebut memiliki kemampuan yang dapat menambah pendapat keluarganya. Pada segi fisik ini terdapat sebanyak enam responden yang tidak dapat mengembangkan keterampilannya dan sebelas responden yang tidak lagi bekerja setelah melangsungkan perkawinan. Sedangkan dengan bekerjanya seorang perempuan, maka kebutuhan aktualisasi dirinya tersebut dapat terpenuhi. Bekerja merupakan cara untuk mengatualisasikan diri sesuai dengan pendapat Maslow (dalam Dewi: 2006) bahwa salah satu kebutuhan manusia adalah 
aktualisasi diri. Dengan bekerja seseorang dapat berkarya, berkreasi, mencipta, mengekspresikan diri, mengembangkan diri dengan orang lain, membagikan ilmu dan pengalaman, menghasilkan sesuatu, penerimaan dan prestasi. Jika dilihat dari pekerjaan pasangan suami seluruh responden yang perempuan dirasa perlu untuk bekerja dan membantu kebutuhan finansial keluarganya.

Pada segi mental, terdapat tiga responden dari lima belas responden yang merasa tertekan dan stres setelah melangsungkan perkawinan dan tujuh responden yang merasa kebutuhan pribadinya terganggu setelah melangsungkan perkawinan. Untuk itu sebelum menikah pasangan perlu mengetahui faktor psikologis yang harus disiapkan. Jika responden masih dalam tahap perkembangan maka hal-hal yang perlu diperhatikan seperti kematangan emosi, toleransi, saling pengertian, saling mengerti, akan kebutuhan masing-masing pihak, dapat saling memberi dan menerima kasih sayang, saling mempercayai, adanya keterbukaan dalam komunikasi dan kesiapan diri untuk lepas dari orang tua untuk hidup mandiri merupakan pemahaman yang harus dimiliki saat sudah menikah baik untuk dirinya sendiri ataupun kepada pasangan (Walgito, 2000 dalam Dewi, 2006).

Kemudian pada segi pendidikan ini merupakan segi risiko tertinggi dimana seluruh responden sebanyak lima belas responden memiliki tingkat pendidikan yang rendah dan kondisi pendidikan yang tidak memungkinkan untuk melanjutkan pendidikan setelah melangsungkan perkawinan. Apabila ditinjau dari segi sosial, dengan perkawinan maka mengurangi kebebasan pengembangan diri serta mengurangi kesempatan melanjutkan pendidikan ke jenjang yang tinggi. Padahal pendidikan yang tinggi dianggap perlu untuk kaum perempuan karena dapat meningkatkan taraf hidup dan membuat keputusan yang menyangkut masalah kesehatan mereka sendiri. Seorang perempuan yang lulus dari perguruan tinggi akan lebih mudah mendapat pekerjaan dan mampu berperilaku hidup sehat bila dibandingkan dengan seorang perempuan yang memiliki pendidikan rendah. Semakin tinggi pendidikan seorang perempuan maka ia semakin mampu mandiri dengan sesuatu yang menyangkut diri mereka sendiri. (Widyastuti dkk, 2011: 108).

Pada segi kependudukan peneliti memfokuskan untuk meneliti responden pada jumlah anak dan keikutsertaan program KB. Berdasarkan hasil penelitian, terdapat enam responden yang memiliki jumlah anak lebih dari 2 orang sebagaimana yang disarankan oleh BKKBN pada program Keluarga Berencana. Keluarga Berencana adalah upaya mengatur kelahiran anak, jarak dan usia ideal melahirkan, mengatur kehamilan, melalui promosi, perlindungan, dan bantuan sesuai dengan hak reproduksi untuk mewujudkan keluarga yang berkualitas (Fave, 2014). Dimana jumlah anak yang dianggap ideal oleh program ini adalah 2 orang dengan pembatasan yang bisa dilakukan dengan menggunakan alat kontrasepsi atau penanggulangan kelahiran seperti pil, suntik, kondom dan sebagainya. Keikutsertaan responden terhadap program tersebut hanya sebagai cara untuk menunda sementara atau memberi jarak terhadap kelahiran anak-anak mereka. Ini membuktikan bahwa perkawinan usia muda ikut menyumbangkan jumlah angka kelahiran dan angka kependudukan.

Berdasarkan hasil wawancara, dari lima belas responden yang diteliti terdapat satu responden yang berisiko pada segi kelangsungan rumah tangganya. Kualitas hubungan dapat memengaruhi cara individu dalam membingkai persoalan konflik. Suatu topik konflik seperti perilaku tidak mengerjakan tugas dapat berubah menjadi konflik yang mendalam, apabila bingkai sebagai karakteristik kepribadian, seperti sikap tidak bertanggung jawab. (Vuchinich, 2003 dalam Lestari 2012: 103).

Risiko pada segi kelangsungan rumah tangga ini menjadi kekurangan dari perkawinan usia muda, meskipun tidak semua responden mengalaminya. Namun seharusnya tidak ada risiko seperti ini. Kematangan psikologis yang belum tercapai sehingga keluarga mengalami kesulitan mewujudkan keluarga yang berkualitas tinggi. Adanya konflik dalam keluarga membuka peluang untuk mencari pelarian pergaulan diluar rumah bahkan tingkat perceraian yang tinggi karena adanya kegagalan keluarga dalam melewati berbagai macam permasalahan meningkatkan risiko perceraian (Widyastuti, 2011:108). 


\section{KESIMPULAN}

Seluruh responden memiliki risiko pada keenam segi yang diteliti yaitu segi kesehatan, segi fisik, segi mental, segi pendidikan, segi kependudukan dan segi kelangsungan rumah tangga yang dihasilkan dari perkawinannya di usia muda. Risiko masing-masing responden berbeda sesuai dengan penjabaran di atas yang diteliti sesuai dengan teori dan hasil turun lapang.

\section{SARAN}

1. Diharapkan perempuan yang menikah di usia muda pada saat diawal kehamilan selalu konsultasi pada dokter dan pendewasan usia kehamilan dengan penggunaan alat kontrasepsi sehingga kehamilan pada waktu usia reproduksi sehat.

2. Bagi perempuan disarankan untuk bekerja mengingat kebutuhan finansial dalam rumah tangga dan kebutuhan untuk mengaktualisasikan diri. Pada segi mental sebelum melangsungkan perkawinan harus mempersiapkan diri untuk menjadi individu yang lebih tegar, selalu meminta nasehat orang tua, konsultasi kepada psikolog agar memahami satu sama lain sebelum menikah, saling percaya, tidak mengutamaka ego, saling menghargai perbedaan pasangan, saling berkomunikasi dan memahami perubahan yang akan terjadi didalam hidup.

3. Disarankan berdasarkan program KB, pasangan yang akan menikah sebaiknya membicarakan terkait rencana jumlah keturunan yang inginkan dan disesuaikan dengan program pemerintah agar dapat menekan angka kependudukan serta meminimalisir angka kelahiran yang terlalu dekat sehingga SDM yang dihasilkan dapat berkualitas baik.

4. Untuk institusi diharapkan dapat menggalakan program Pendewasaan Usia Perkawinan agar dapat menurunkan angka perkawinan usia muda khususnya pada masyarakat Desa Sriamur dengan mensosialisasikan manfaat yang akan diterima dengan menikah diusia yang tepat dan risiko-risiko yang akan diterima jika melakukannya di usia yang muda.

\section{DAFTAR PUSTAKA}

Badan Pusat Statistik. 2012. Survei Demografi dan Kesehatan Indonesia (SDKI). 2012. Badan Pusat Statistik. Jakarta.

Dewi, I.S. 2006. Kesiapan Menikah Pada Wanita Dewasa Awal yang Bekerja. Skripsi. Fakultas Kedokteran, Universitas Sumatera Utara. Medan

Fave, A. 2014. Program Kependudukan dan KB (PPKDB). Dinas Kependudukan dan KB (PPKDB). Jakarta.

Kantor Urusan Agama Tambun Utara. 2015. Data Usia Perkawinan Per J anuari- Desember 2015. KUA Tambun Utara. Bekasi.

Lestari, S. 2012. Psiklogi Keluarga. Kencana Prenada Media Grup. Jakarta.

Majalah Hamil Online. 2014. Penyebab Keguguran Hamil Muda. http://hamil.co.id/masalahkehamilan/keguguran/penyebab-keguguran-hamil- muda. html. Tanggal akses 12 Juli 2017.

Moleong, R. 2010. Metode Penelitian Kualitatif. PT Remaja Rosdakarya. Bandung.

Sugiyono. 2012. Metode Penelitian Kuantitatif, Kualitatif, dan Kombinasi (Mixed Methods). Alfabeta. Bandung

Widyastuti, Y., Anita, R., Yuliasti, E.P. 2011. Kesehatan Reproduksi. Fitramaya. Yogyakarta 